\title{
Shifted baselines and the policy placebo effect in conservation
}

\author{
Samantha Lovell, Ayana Elizabeth Johnson \\ Robin Ramdeen and Loren McClenaChan
}

\begin{abstract}
Coastal ecosystems have been degraded by human activity over centuries, with loss of memory about past states resulting in shifted baselines. More recently conservation efforts have resulted in localized recoveries of species and ecosystems. Given the dynamism of ecosystem degradation and recovery, understanding how communities perceive longterm and recent changes is important for developing and implementing conservation measures. We interviewed stakeholders on three Caribbean islands and identified a shifted baseline with respect to the extent and degree of long-term declines in marine animal populations; stakeholders with more experience identified more species as depleted and key species as less abundant than those with less experience. Notably, the average respondent with $<15$ years of experience listed no species as depleted despite clear evidence of declines. We also identified a phenomenon we call the policy placebo effect, in which interviewees perceived some animal populations as recently recovering following passage of new conservation legislation but in the absence of evidence for actual recovery. Although shifted baselines have a negative effect on conservation as they can lower recovery goals, the outcomes of a policy placebo effect are unclear. If the public prematurely perceives recovery, motivation for continued conservation could decline. Alternatively, perception of rapid success could lead communities to set more ambitious conservation goals.
\end{abstract}

Keywords Historical ecology, local ecological knowledge, marine conservation, marine protected areas, policy placebo, recovery, shifting baselines

Supplementary material for this article is available at https://doi.org/10.1017/Soo30605318000169

\section{Introduction}

Tnformation on long-term change is important for conser1 vation and management, particularly in coastal ecosystems,

\footnotetext{
SAmantha Lovell ${ }^{*}$ and Loren McClenachan (Corresponding author) Environmental Studies Program, Colby College, 5351 Mayflower Hill Drive, Waterville, Maine, USA. E-mail lemcclen@colby.edu

Ayana Elizabeth Johnson, Ocean Collective, Brooklyn, New York, USA

Robin Ramdeen, Waitt Institute, Montserrat, West Indies

${ }^{*}$ Also at: Environmental Defense Fund, Washington, DC, USA

Received 2 August 2017. Revision requested 20 October 2017.

Accepted 18 January 2018. First published online 18 October 2018.
}

whose history of degradation can be obscured by a lack of ecological data from the past (Jackson et al., 2001). Failure to document past change can lead to the shifting baseline syndrome, in which knowledge of past ecosystem productivity is lost over the course of generations (Pauly, 1995). Shifted baselines have been documented among marine resource users; for example, in both Mexico and Brazil older fishers named more fish species and fishing sites as depleted than younger fishers (Sáenz-Arroyo et al., 2005; Giglio et al., 2015). In Curaçao and Bonaire (Netherlands), fishers' baselines were not shifted because stories of plentiful past catches were passed down within these communities, whereas scuba divers had unrealistically positive perceptions of the health of the reefs and fish populations because they lacked this information (Johnson \& Jackson, 2015). Such shifted baselines have implications for conservation, as they may lead to reduced restoration targets for exploited species (McClenachan et al., 2012, 2018).

Change in Caribbean marine ecosystems has been documented over century-long time scales, with historical losses of large vertebrates fundamentally altering trophic dynamics (McClenachan et al., 2006; McClenachan \& Cooper, 2008), losses of herbivorous fishes such as parrotfish (Scarus spp.) contributing to declines in reef accretion rates (Cramer et al., 2017), and reductions in the spatial distribution of coral reef habitats (McClenachan et al., 2017). In recent decades, the three-dimensional structure of Caribbean reefs has been reduced (Alvarez-Filip et al., 2009), and hard coral cover declined on average by $50 \%$ between the 1970 s and early 2000s, with shifts to non-framework building species (Jackson et al., 2014). Together with ongoing overfishing, these changes have led to declines in the density of both exploited and unexploited reef fishes (Paddack et al., 2009). A phase shift from coral to algal dominance was triggered and maintained by a combination of a disease in the sea urchin Diadema antillarum in the early 1980s, overexploitation of parrotfish and other algal grazers (Jackson et al., 2014), and land-based pollution (Cramer et al., 2012, 2015). More recently, climate change, disease, and invasive species have added additional stresses (Hoegh-Guldberg et al., 2007; Green et al., 2012; Randall \& van Woesik, 2015).

Despite these longer-term declines in Caribbean marine ecosystems, some recent conservation efforts have been successful, and localized recoveries of marine species and ecosystems are occurring. Although Caribbean green turtle 
Chelonia mydas populations are estimated to be $<1 \%$ of their historical abundance (McClenachan et al., 2006), effective local conservation has resulted in local population recovery (Hays, 2004; Troëng \& Rankin, 2005). Parrotfish recovery has been documented after a ban on fish traps (O'Farrell et al., 2016), giving hope for broader ecosystem recovery, as these grazing fish facilitate coral growth (Cramer et al., 2017). In marine reserves where parrotfish and other herbivores are protected, coral recovered from bleaching significantly faster compared to coral in unprotected areas (Mumby \& Harborne, 2010). Diadema urchins have also recovered locally, facilitating coral recruitment and increased abundance of juvenile coral on Caribbean reefs (Edmunds \& Carpenter, 2001; Carpenter \& Edmunds, 2006).

Although both long-term declines and recent recoveries in the Caribbean have been documented, the ways in which resource users view these changes have not been well studied. Here, we use local ecological knowledge to understand how residents on the Caribbean islands of Montserrat, Antigua and Barbuda perceive the timing and extent of long-term and recent changes in a suite of marine taxa, and the causes of these changes. Our results illuminate perceptions about ecosystem change and the implications of those perceptions on development and implementation of conservation measures.

\section{Methods}

We conducted in-person interviews with fishers and divers on the islands of Montserrat, Antigua and Barbuda in January 2016. Interviewees were identified and introductions facilitated by the Waitt Institute's Blue Halo Initiative (Waitt, 2016), and by approaching fishers as they returned from fishing and/or were selling their catches. After each interview we asked the interviewee if he or she knew of any other fishers or divers we should speak with, a technique known as snowball sampling. This approach was intended to target knowledgeable community members, to assess the perception of those most likely to be aware of changes.

We identified 10 marine animal taxa of historical, cultural or economic importance to the islands. Four were individual species: spiny lobster Panulirus argus, common octopus Octopus briareus, queen conch Strombus gigas and barracuda Sphyraena barracuda. Six were broader taxonomic groupings: sharks (Carcharhinidae), groupers (Epinephelinae), sea turtles (Chelonia mydas and Eretmochelys imbricata), snappers (Lutjanidae), parrotfish (Scarus spp.), and hard coral (Scleractinia). For each of the 10 taxa of interest we asked interviewees to indicate abundance as absent, rare, common, abundant or superabundant in January 2016, 10 years earlier and 20 years earlier. Interviewees with $<10$ or $<20$ years of experience were only asked to describe change over a time frame that corresponded to the duration of their experience, and interviewees only provided descriptions of taxa they had personally observed. During interviews on Montserrat we asked about abundance before and after the eruption of the Soufriére Hills volcano (1995) because the eruption and resulting ash caused large-scale damage to the marine environment surrounding the island. We also asked interviewees to identify additional species whose abundance they perceived to be increasing or decreasing over these same time scales. Responses were recorded on a categorical scale, with absence equivalent to 1 and superabundant equivalent to 5 . We then compared the mean perceived abundance ranking for each taxon over time and among islands. To confirm trends derived from ranked abundances we also asked interviewees if they had perceived a change in abundance over time in these key taxa. Finally, we asked interviewees about any additional changes they had observed in these taxa (e.g. geographical range or body size), and causes of any perceived changes.

To evaluate evidence for shifted baselines, we compared both the perceived extent and degree of depletion of marine taxa to interviewees' years of experience fishing or diving. Extent of depletion was measured as the number of species perceived as declining; degree of depletion was measured as the perceived current abundance of the five species most commonly cited as declining. For any species determined to be increasing, we identified conservation policies that would have affected the populations of these species, comparing the timing of implementation of these policies to the generation time of each species, to determine if protection had been in place long enough for a change to have resulted. To put these changes into an ecological and historical context we also compared interviewee perceptions of change to all available ecological and historical information on changes in those taxa.

\section{Results}

We conducted a total of 40 interviews: 20 on Montserrat, 15 on Barbuda and five on Antigua (Supplementary Table 1). The mean age of interviewees was 43 years (range 19-74), and the mean experience fishing or diving was 23 years (range 2-60). We grouped interviewees into three age categories: $\leq 35$ years ( 14 interviewees), $35-55$ years (14 interviewees), and $\geq 55$ years (12 interviewees) and three experience categories: low experience, $\leq 15$ years (12 interviewees), medium experience, 15-30 years (14 interviewees), and high experience with $\geq 30$ years (12 interviewees). Thirty-seven interviewees were men, and three women.

Perceptions of the timing, extent and drivers of change in marine taxa

Across the 40 interviews, 33 taxa were identified as declining by at least one interviewee, which included all 10 of the taxa of interest and an additional 23 taxa (Supplementary Table 2). Individual interviewees cited a median of 3.98 
(range o-11) taxa as declining. The five taxa most commonly cited as declining were coral, lobster, conch, grouper and parrotfish, each of which had mean perceived abundance rankings that declined significantly over the 20-year time period (Fig. 1). Coral were perceived as having declined from 4.09 (abundant) to 2.53 (rare to common; $F(2,82)=32.79, \mathrm{P}<0.01)$, lobster from 4.20 to $2.99(F(2,90)=$ 18.3, $\mathrm{P}<0.01)$, conch from 3.96 to $2.79(F(2,89)=15.52$,
$\mathrm{P}<0.01)$, grouper from 3.96 to $2.79(F(2,89)=13.51, \mathrm{P}<0.01)$, and parrotfish from 4.05 to $3.03(F(2,86)=11.32, \mathrm{P}<0.01)$. These values were significant $(\mathrm{P}<\mathrm{0.01})$ after Bonferroni corrections for multiple testing. Interviewees from Antigua and Barbuda reported higher mean abundance than those from Montserrat, with perceived mean abundances of lobster, conch, grouper, octopus, snapper and shark significantly higher for at least one of the time periods (Supplementary
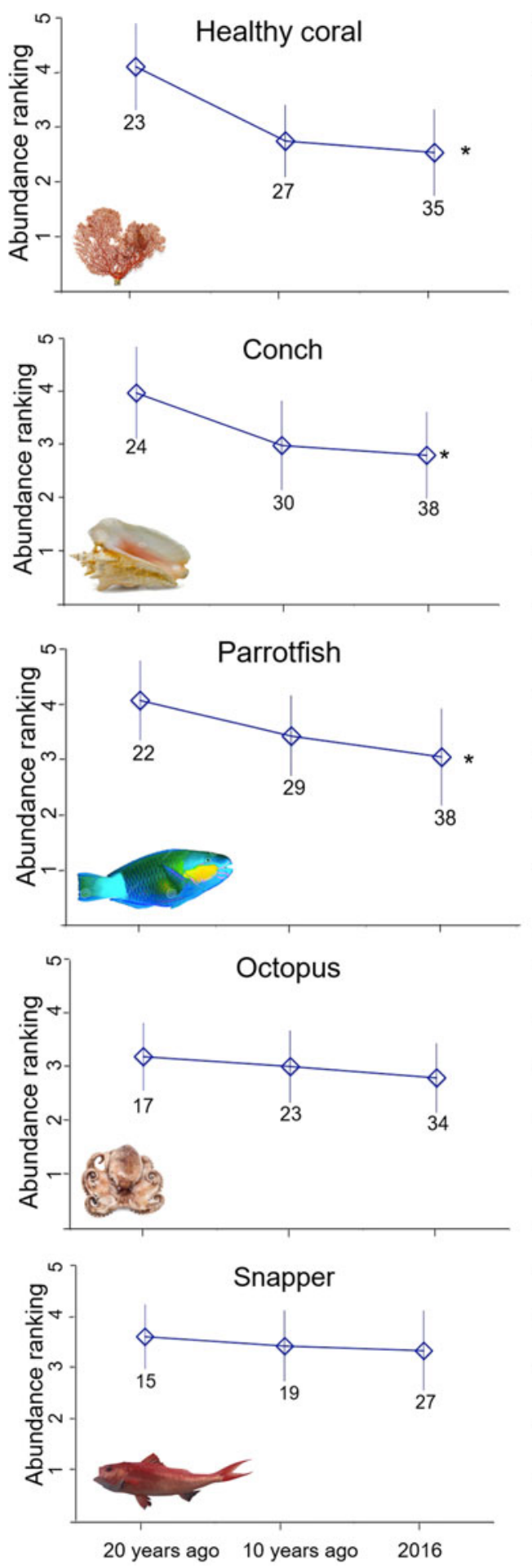
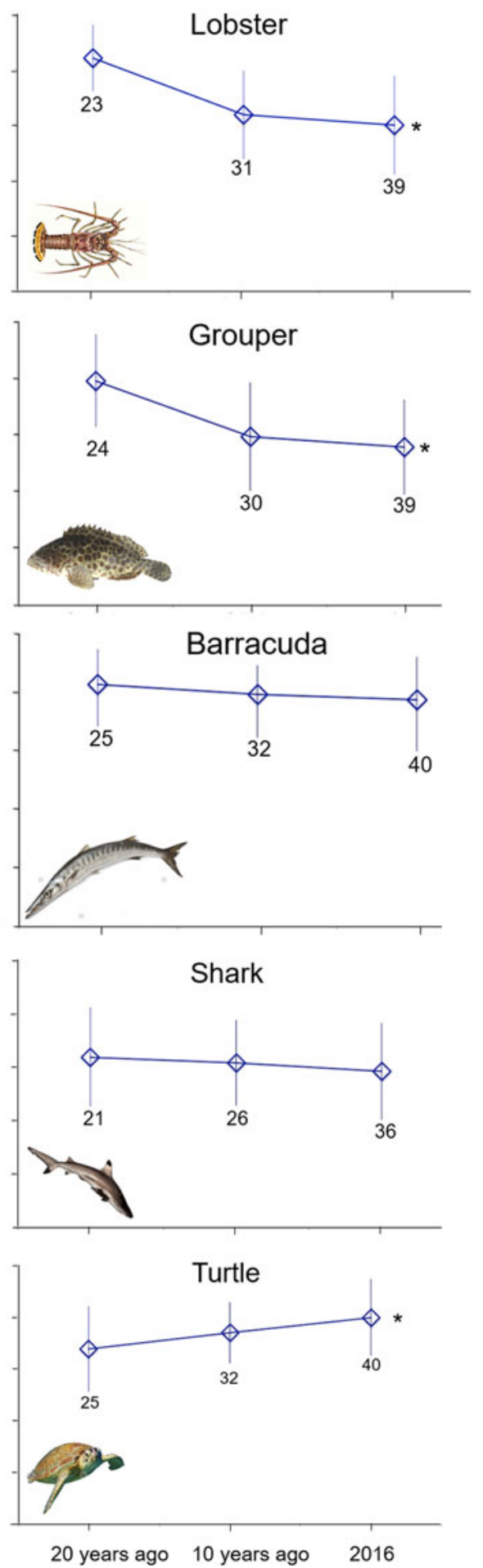

FIG. 1 Mean perceived abundance (1, absent; 2, rare; 3, common; 4, abundant; 5, superabundant; with SD bars) for the 10 species of interest. Significant changes in perceived abundance are indicated with an asterisk. 
TABLE 1 Reasons cited for species decline or increase (number of people citing reason), including recent increases, with illustrative example responses.

\begin{tabular}{|c|c|}
\hline Reason (n) & Example response (location, interviewee age) \\
\hline \multicolumn{2}{|l|}{ Decline } \\
\hline Volcano (41) & $\begin{array}{l}\text { I would give [coral cover] a percentage, we have about } 40 \% \text { of the corals we used to have. It was all the } \\
\text { volcano...the ash definitely took out loads of coral. (Montserrat, 56) }\end{array}$ \\
\hline Overfishing (35) & $\begin{array}{l}\text { When it comes to mating, [grouper] congregate, so people used to go out } \& \text { take a whole breeding amount } \\
\text { of them. (Barbuda, 42) }\end{array}$ \\
\hline Hurricanes (14) & $\begin{array}{l}\text { I used to see many [parrotfish] in terminal phase, but they were a casualty of the hurricanes. . the first big } \\
\text { hurricane was Hugo in } 1989, \text { \& parrotfish washed up along the shore along with other fish. (Barbuda, 55) }\end{array}$ \\
\hline Habitat loss (10) & $\begin{array}{l}\text { The parrotfish have lost their habitat. . .everywhere there used to be parrotfish... you couldn't go snor- } \\
\text { keling without seeing a ton of them. (Montserrat, 33) }\end{array}$ \\
\hline Poor management (6) & Lack of enforcement of regulations by officials. [referring to lobster decline] (Antigua, 46) \\
\hline Sedimentation (6) & $\begin{array}{l}\text { Sedimentation is also a huge issue, especially in areas with storm damage. The [coral] species currently } \\
\text { there get majorly damaged in large storms. (Montserrat, 45) }\end{array}$ \\
\hline Water quality (3) & $\begin{array}{l}\text { The decline in sharks is associated with declining water quality. The beaches right off the lagoon are } \\
\text { spawning areas for sharks, with bad water quality you will have less fish \& less shark. (Barbuda, 55) }\end{array}$ \\
\hline \multicolumn{2}{|l|}{ Increase } \\
\hline Legislation (16) & $\begin{array}{l}\text { Parrotfish were first banned the year before last because people saw the populations were depleted, now } \\
\text { the populations have risen a lot. (Antigua, 64) }\end{array}$ \\
\hline Cultural shift/ecotourism (15) & $\begin{array}{l}\text { People respect them [the turtles]... even if it was in season \& I could legally catch a turtle, I wouldn't. The } \\
\text { tourists would not take it too nicely. (Montserrat) }\end{array}$ \\
\hline Reduced fishing (11) & $\begin{array}{l}\text { You have less fishing for sharks now... some folks used to go out for sharks. Now that is only occasionally. } \\
\text { (Montserrat, 45) }\end{array}$ \\
\hline Enforcement (2) & $\begin{array}{l}\text { Things have been looking up. Grouper season is closed right now. We work hard to have enforcement. } \\
\text { (Barbuda, 42) }\end{array}$ \\
\hline
\end{tabular}

Fig. 1). Perceived causes of declines in species abundance included overfishing, hurricanes and poor enforcement of fisheries rules (Table 1, Supplementary Fig. 2). The most frequently cited reason for species decline on Montserrat was the 1995 Soufriére Hills volcanic eruption, whereas interviewees from Barbuda and Antigua most often cited overfishing.

In total 21 taxa were identified as increasing by at least one interviewee (Supplementary Table 2), including six of the 10 taxa of interest and 15 additional taxa. Individual interviewees cited a median of 1.75 taxa (range $0-4$ ) as increasing. Turtles were most frequently cited as increasing, and were the only taxon that had significantly higher mean perceived abundance rankings in January 2016 compared to 20 years earlier, increasing from 3.38 to $3.99(F(2,92)=5.56$,
P > 0.01; Fig. 1). Additionally, five taxa (lobster, grouper, parrotfish, snapper and conch) were described by at least one interviewee as declining overall, but experiencing a recent increase in the last 5 years (Supplementary Table 2). Increases were most frequently attributed to conservation legislation, which was cited a total of 16 times as a reason for increase in populations of grouper, parrotfish, lobster, conch and turtle. Recent legislation includes implementing closed seasons for fishing on Antigua and Barbuda, species protections and marine reserves on Barbuda, and closed seasons for hunting turtles on all three islands.

In addition to changes in abundance, interviewees described changes over time in species composition, catch per unit effort, and target species' sizes (Table 2). Fishers

TABLE 2 Examples of interviewee perceptions (number of people with perception) of changes in the marine environment.

\begin{tabular}{ll}
\hline Perceived change $(\mathrm{n})$ & Example response (location, interviewee age) \\
\hline Loss of large predators (7) & $\begin{array}{l}\text { [Spanish Point] was massively different [when I was younger]. Children would go down \& } \\
\text { shoot decent sized fish day after day. Now you only see...the smaller fish, not the big } \\
\text { predatory fish anymore. Now you see the coneys, the small reef fish, you don't really see the } \\
\text { big grouper at all anymore. (Antigua, 45) } \\
\text { You just would not believe the size of the fish we used to get here. (Montserrat, 56) }\end{array}$ \\
$\begin{array}{ll}\text { Change in size of target species (12) } \\
\text { I used to come in by midday \& have my total catch. Now it takes more hours to catch what we } \\
\text { advanced technology (7) }\end{array}$ & $\begin{array}{l}\text { used to catch. I need to use different gear \& go to different locations. (Barbuda, 56) } \\
\text { Depletion of nearshore fishing grounds (7) }\end{array}$ \\
& $\begin{array}{l}\text { I used to free dive for a long time \& [grouper] were always in the shallows, now they have } \\
\text { moved out into deeper waters. (Barbuda, 26) }\end{array}$ \\
\hline
\end{tabular}


mentioned increased difficulty catching large predators, smaller body sizes of species, depletion of fishing grounds, and the need for advanced technology and increased effort compared to their earlier experiences. When discussing these changes eight respondents independently described the 1980 os and 1990 os as a benchmark for ecosystem health, referring to higher abundances of marine animals, larger fish, less fishing pressure, and healthier coral. For example, when describing parrotfish abundance on Barbuda, one interviewee said, 'the population was very high back in the 1980 s and 1990s' and also indicated that individual size had decreased over this same time period. On Montserrat in particular interviewees used the ecosystem before the volcanic eruption as a baseline against which to compare current abundance. For example, interviewees would commonly say 'since the volcanic crisis, [the abundance of snapper] is not the same.' This decadal timescale is relevant because two major events occurred that affected local reefs: the Caribbean-wide Diadema die-off in 1982 and the volcanic eruption in 1995. This date range indicates that interviewees are locating their views of pristine reefs between these two major disturbance events.

\section{Evidence for a shifted baseline among resource users}

We found strong evidence for a shifted baseline in resource users' perceptions of the extent and degree of declines, with experience rather than age being the key determinant of perception of decline, and with no difference between fishers and divers. Notably, interviewees with $<15$ years of experience reported a median of 0.67 species as depleted, whereas interviewees with $>30$ years of experience reported a median of 6.00 taxa as depleted (Fig. 2a). The difference in median number of species mentioned as declining was significant across all experience levels $(F(2,37)=22.28, \mathrm{P}<0.01)$.

Our second metric of the shifting baseline syndrome was the perception of the current abundance for the five taxa most commonly cited as declining (coral, lobster, conch, parrotfish and grouper). Interviewees with more experience were more likely to consider these five taxa as being less abundant; interviewees with $<30$ years of experience typically described the key taxa as common (a rating of 3) compared to those with $>30$ years of experience, who described the same taxa as rare (a rating of 2, Fig. $2 b$ ). Only interviewees with high levels of experience described any of the five key taxa as absent (rating of 1), whereas only those with medium and low levels described any taxa as superabundant. Mean abundance rankings were significantly different only between interviewees with low and high levels of experience $(t(\mathrm{df})=235.51, \mathrm{P}=0.05)$. There were no significant differences across age categories in perceptions of either extent or degree of change.
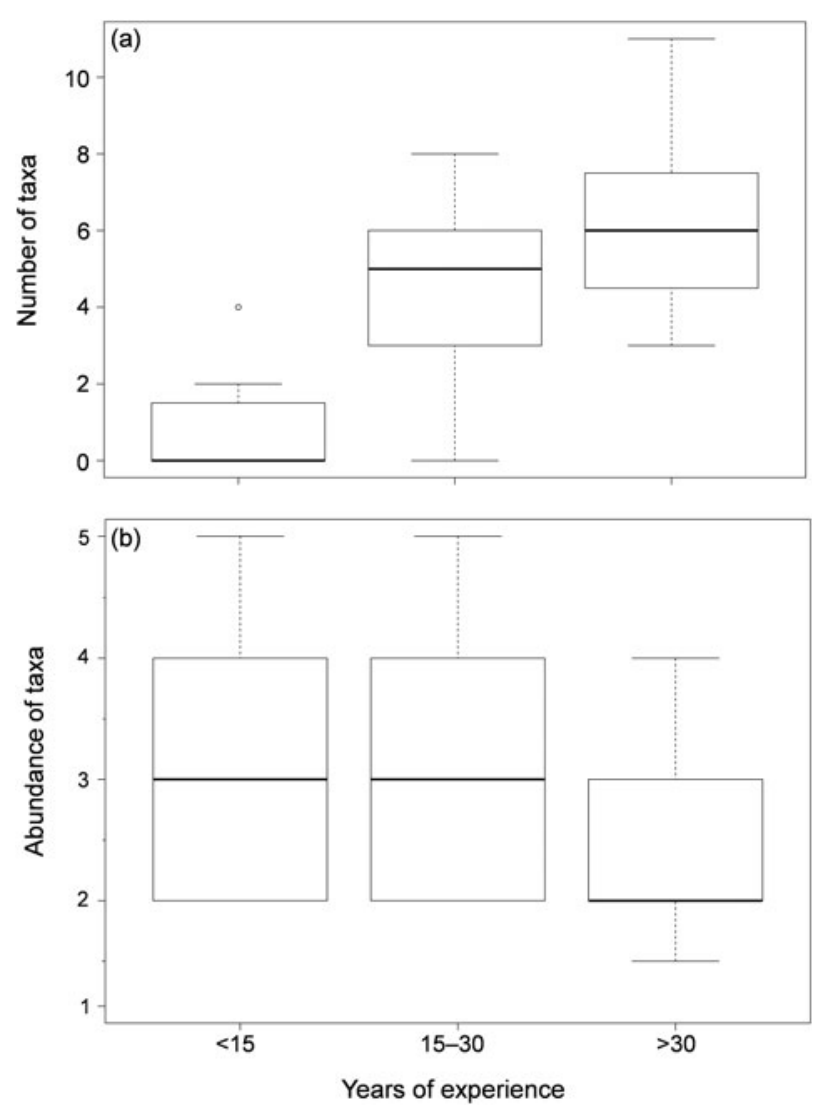

FIG. 2 (a) Number of taxa perceived to be declining, and (b) perceived current abundance of the five taxa most cited as declining: coral (Scleractinia), lobster Panulirus argus, conch Strombus gigas, parrotfish (Scarus spp.), and grouper (Epinephelinae). Rankings are as follows: 1, absent; 2, rare; 3, common; 4, abundant; 5, superabundant. Respondents are grouped by years of fishing or diving experience $(<15,15-30$ and $>30$ years). The horizontal line represents the median, the box the first and third quartiles, and the caps the range of responses.

\section{The policy placebo effect}

In addition to this shifted baseline, we identified what we term a policy placebo effect, in which recent local conservation efforts and new legislation result in the impression that taxa have increased in abundance before that is reasonably possible given the characteristics of the species. A subset of our interviewees reported that several key taxa (turtles, lobster, grouper, parrotfish and conch) had increased in abundance in recent years, which was frequently ascribed to new legislation and other local conservation efforts (Table 3 ). This perceived association was most striking for turtles, with half of interviewees mentioning that local turtle populations are increasing in response to conservation efforts. These conservation programmes and legislation include a size limit and closed season on Montserrat, which was implemented in 2002 (14 years prior to interviews), and a turtle hatchery and a closed season on Antigua and Barbuda, which both began in 2013 (3 years prior to interviews). However, green turtles have a generation 
TABLE 3 Marine faunal groups perceived to be recently increasing, by island, with generation time, years since first protection, type and year of protection, per cent of interviewees describing them as increasing, illustrative quotes and information on current status.

\begin{tabular}{|c|c|c|c|c|c|c|c|}
\hline Taxa (generation time) & Island & $\begin{array}{l}\text { Years since } \\
\text { first } \\
\text { protection }\end{array}$ & $\begin{array}{l}\text { Type \& year of } \\
\text { protection }\end{array}$ & $\begin{array}{l}\% \text { of intervie- } \\
\text { wees noting } \\
\text { increase }\end{array}$ & Illustrative quote & Status & Source \\
\hline \multirow[t]{2}{*}{$\begin{array}{l}\text { Green Chelonia mydas \& } \\
\text { hawksbill Eretmochelys } \\
\text { imbricata turtles (35-50 } \\
\text { years) }\end{array}$} & Montserrat & 14 & $\begin{array}{l}\text { Size limit \& closed } \\
\text { season }(2002)\end{array}$ & 50 & $\begin{array}{l}\text { I have never seen so many turtles } \\
\text { in Montserrat. People used to } \\
\text { make a living off of harvesting, } \\
\text { but it is protected now. }\end{array}$ & $\begin{array}{l}\text { Critically small } \\
\text { populations }\end{array}$ & $\begin{array}{l}\text { Maylan (1983), } \\
\text { Groombridge \& Luxmore } \\
\text { (1989), Godley et al. (2004) }\end{array}$ \\
\hline & $\begin{array}{l}\text { Antigua \& } \\
\text { Barbuda }\end{array}$ & 3 & $\begin{array}{l}\text { No allowed harvest } \\
\text { without declared } \\
\text { season }(2013)\end{array}$ & 50 & $\begin{array}{l}\text { There are too many turtles \& } \\
\text { there keep being more } \& \text { more: no } \\
\text { one is troubling the turtles. }\end{array}$ & $\begin{array}{l}\text { Low abundance of } \\
\text { nesting turtles }\end{array}$ & $\begin{array}{l}\text { Maylan (1983), } \\
\text { Groombridge \& Luxmore } \\
\text { (1989), } \\
\text { Barbuda Council (2013) }\end{array}$ \\
\hline $\begin{array}{l}\text { Parrotfish (Labridae) } \\
\text { (3 years) }\end{array}$ & $\begin{array}{l}\text { Antigua \& } \\
\text { Barbuda }\end{array}$ & 3 & $\begin{array}{l}\text { Closed season on } \\
\text { Antigua \& Barbuda } \\
\text { (2013), banned on } \\
\text { Barbuda (2014) }\end{array}$ & 25 & $\begin{array}{l}\text { The parrotfish are starting to get } \\
\text { better since the area has been } \\
\text { closed off. }\end{array}$ & $\begin{array}{l}\text { Low abundance of } \\
\text { three species }\end{array}$ & $\begin{array}{l}\text { Barbuda Council (2013, } \\
\text { 2014), Ruttenberg et al. } \\
\text { (2013) }\end{array}$ \\
\hline $\begin{array}{l}\text { Lobster Panulirus argus } \\
\text { ( } 4-10 \text { years) }\end{array}$ & $\begin{array}{l}\text { Antigua \& } \\
\text { Barbuda }\end{array}$ & 3 & $\begin{array}{l}\text { Closed season \& } \\
\text { minimum size limit, } \\
\text { gear restrictions } \\
(2013)\end{array}$ & 15 & $\begin{array}{l}\text { From the } 2 \text { months they were } \\
\text { banned, there has been a dramatic } \\
\text { increase-they may extend it to } \\
3 \text { months now. }\end{array}$ & $\begin{array}{l}\text { Average size has } \\
\text { declined, many } \\
\text { lobsters of sub-legal } \\
\text { size }\end{array}$ & Barbuda Council (2013) \\
\hline $\begin{array}{l}\text { Grouper (Epinephelinae) } \\
\text { (8-11 years) }\end{array}$ & $\begin{array}{l}\text { Antigua \& } \\
\text { Barbuda }\end{array}$ & 3 & Closed season (2013) & 15 & $\begin{array}{l}\text { Now-seeing it come back } \\
\text { again... surprised to see the size of } \\
\text { them-they are really coming } \\
\text { back now. }\end{array}$ & $\begin{array}{l}\text { Low abundance, } \\
\text { severely depleted } \\
\text { population }\end{array}$ & $\begin{array}{l}\text { Barbuda Council (2013), } \\
\text { Ruttenberg et al. (2013) }\end{array}$ \\
\hline $\begin{array}{l}\text { Conch Strombus gigas } \\
\text { (5 years) }\end{array}$ & $\begin{array}{l}\text { Antigua \& } \\
\text { Barbuda }\end{array}$ & 3 & $\begin{array}{l}\text { Closed season \& } \\
\text { minimum size limit } \\
(2013)\end{array}$ & 5 & $\begin{array}{l}\text { Conch suffered a huge blow... Had } \\
\text { some exporters for conch \& it } \\
\text { created a massive decline... } \\
\text { The population is coming back } \\
\text { now. }\end{array}$ & $\begin{array}{l}\text { Low abundance \& } \\
\text { size compared to } \\
\text { other Caribbean } \\
\text { islands }\end{array}$ & $\begin{array}{l}\text { Barbuda Council (2013), } \\
\text { Ruttenberg et al. (2013) }\end{array}$ \\
\hline
\end{tabular}


time of 35-50 years, and hawksbill 20-40 years. Therefore, with the exception of the turtle hatchery, it is unlikely that these conservation actions and policies could have resulted in population increases within this time frame.

Likewise, parrotfish, lobster, grouper and conch were all considered to be increasing, but with legislation in place for less than one generation time for each group. Conservation policies include the implementation of closed seasons for these other taxa in 2013 (Barbuda Council, 2013). On Barbuda, parrotfish harvesting was banned and a system of extensive marine reserves was created in 2014 (Barbuda Council, 2014). Given that enforcement of these new regulations was implemented slowly on both islands, and the generation times for parrotfish and groupers are 3 to $>10$ years, respectively, it is unlikely that any increases in abundance to date are the result of these policy changes.

\section{Discussion}

Local ecological knowledge, ecological data and historical observations

Our results reveal that, collectively, resource users on three Caribbean islands identify declines in key taxa, including coral, other invertebrates and reef fish. These perceptions are largely confirmed by ecological data. Barbuda has live coral cover as low as $2.6 \%$ (Jackson et al., 2014) and the decline in coral cover during 2005-2008 for the island was estimated to have been 12.7\% (Ruttenberg et al., 2013). Across both Antigua and Barbuda there have been documented declines in reef cover and health (Francis, 2010). In Montserrat the volcanic eruption and continued sedimentation destroyed large portions of reef off the southern and eastern coasts (Ferguson \& Daniel, 2015), consistent with interviewees' responses. Forty per cent of interviewees described grouper and parrotfish as declining; ecological assessments report low abundance of large fish species around Montserrat, Antigua and Barbuda (Francis, 2010; Ruttenberg et al., 2013;
Ferguson \& Daniel, 2015). The decline in invertebrate populations on the islands is also mirrored by interviewee perceptions: $>50 \%$ of interviewees described lobster as declining and $40 \%$ described conch as declining. Declines have occurred in landings of spiny lobster on Barbuda (Peacock, 1974; Albuquerque \& McElroy, 1995) and conch populations are low on Barbuda compared to other Caribbean islands (Ruttenberg et al., 2013).

Despite this alignment of ecological assessments and interviewees' responses, we also identified a shifted baseline in the degree and extent of perceived change in the abundance of key taxa, with years of experience dictating perceptions of decline. Our approach of prioritizing knowledgeable individuals may have underestimated this shifting baseline effect, as many fishers or divers may have less experience than our interviewees. At the same time, even our knowledgeable interviewees were limited in their observations to the past 2-3 decades. The species with the longest generation time and lowest possible recovery rates were not perceived to have declined, whereas the shorter-lived species were. This may be because many of these species were probably depleted before the period observed by any of our interviewees. Although historical information is limited, it suggests reduction in abundances extending back decades or centuries. Historical sources from the 1790 os to early 1900 s describe abundant snapper, sharks and barracuda on Montserrat, Antigua and Barbuda (Riddell, 1792; Coleridge, 1826; Nutting, 1919; Supplementary Table 3) and early maps reference locations named after particular taxa (Fig. 3), usually an indication that the taxa were abundant there. We located five maps published between 1748 and 1977 that referenced our taxa of interest, including sharks, groupers, snappers and lobsters. For example, a 1784 map noted 'sharks without number' west of Antigua and Barbuda, and a 1977 map indicated a location south of Barbuda as having 'excellent spearfishing' for groupers. These observations suggest that these marine species were historically abundant, and may have declined prior to observations by our interviewees. More recent historical information also indicates reef

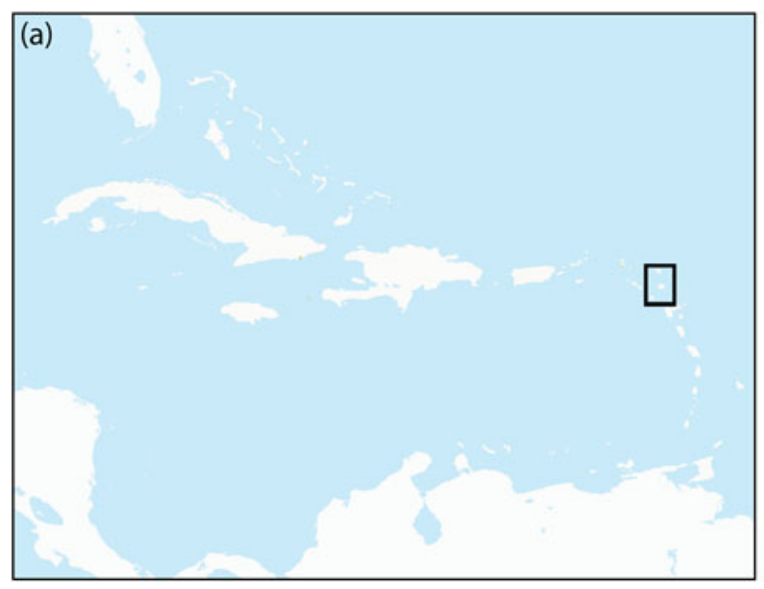

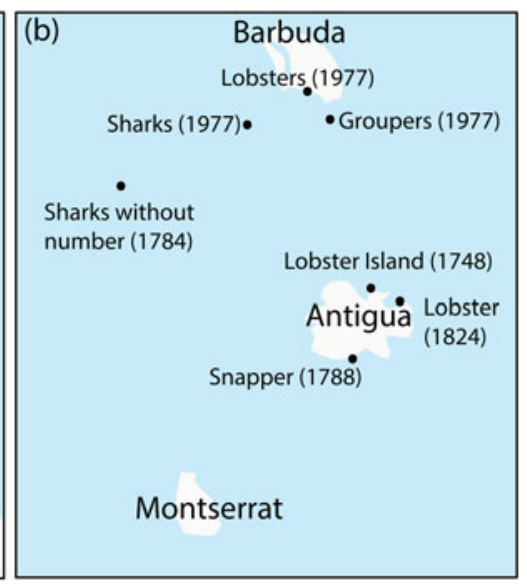

FIG. 3 (a) The Caribbean, with rectangle indicating the location of the islands of Montserrat, Antigua and Barbuda, and (b) places named after marine species, identified from historical maps, with year of map (from: Baker, 1748; De La Rochette, 1784; Luffman, 1788; Fielding, 1824; Nicholson \& Sons, 1977). 
ecosystems were already significantly degraded by the mid 1990s. Even prior to the volcanic eruption, lobster landings were reduced on Montserrat, and conch harvests showed signs of depletion as early as the 1960s (Luckhurst \& Marshalleck, 1995; Jeffers, 1996).Therefore, the fact that several interviewees described the ecosystem of 20-30 years ago for Antigua and Barbuda and pre-volcano (1995) for Montserrat as 'pristine,' and used the state of the ecosystem in that time period as a baseline against which to compare current conditions is further indication of a shifted baseline in the perception of pristine reefs.

\section{Natural disasters, shifted baselines and the policy placebo}

Interviewees referring to the environment of 20-30 years ago as pristine exemplifies the insidious nature of the shifting baseline syndrome. Description of Montserrat's prevolcano environment as pristine suggests the role of natural disasters in obscuring baselines. Although nearshore ecosystems were substantially altered by the volcano, this emphasis could mask anthropogenic effects on marine species. Interviewees from Montserrat consistently reported taxa as less abundant than on the other two islands, both before and after the volcano (Supplementary Fig. 2), which may be a result of lowered expectations for abundance, consistent with the shifting baseline syndrome. Work on the syndrome has typically focused on effects of chronic exploitation, and the role of natural disasters in recalibrating expectations for nature requires exploration.

There was a clear disparity between ecological data and interviewee perceptions of recent increases in species protected by legislation, which we suggest can be attributed to the occurrence of a policy placebo effect. Although the term placebo effect is typically confined to the medical field, it is broadly defined as an effect that is initiated and maintained by the expectation of a symptom change (Price et al., 2008). As we did not anticipate such an effect, our interviews were not designed to address this issue, and therefore we can only speculate on its causes. Fishers may have reported recoveries in the hope this would result in removal of fishing restrictions. However, it could also be the result of poor understanding of life histories and recovery times, wishful thinking in the wake of recent legislation, a response to well publicized conservation actions, or even the modern culture of instant gratification.

Although the policy placebo effect may appear benign, it could be detrimental to conservation, particularly when coupled with the shifting baseline syndrome, which is likely to lower both targets for recovery and motivation for continued restoration efforts. The policy placebo effect may similarly reduce motivation for restoration and continued conservation, if resource users believe a population has recovered. On the other hand, the effect could inspire further restoration efforts and trust in management decisions because people perceive they are effective. In either case, this placebo effect illuminates the need to pair local ecological knowledge with ecological monitoring and the use of historical data to understand long-term change. Although local ecological knowledge is useful when it is taken cumulatively and when resource users have direct experience that overlaps with periods of decline, the perceptions of resource users (especially those without long-term experience) are not always consistent with actual current or past ecological states. To manage and restore ecosystems effectively, we need to interweave firm understandings of history, ecology and local knowledge.

Acknowledgements We thank Colby College's Goldfarb Center for funding SL, two anonymous reviewers for valuable comments, Manny Gimond for technical assistance, and Jeremy Jackson for facilitating author collaboration and inspiring this work.

Author contributions Project conception: AJ and LM; data collection: SL and RR; data analysis and visualization: SL and LM; writing and editing: SL and LM.

\section{Conflicts of interest None.}

Ethical standards This research was deemed Institutional Review Board exempt by the Institutional Review Board Chair of Colby College. Interviews on Montserrat were conducted after obtaining a Memorandum of Understanding with the Montserrat Department of Environment.

\section{References}

Albuquerque, K.D. \& McElroy, J.L. (1995) Antigua and Barbuda: A Legacy of Environmental Degradation, Policy Failure, and Coastal Decline. Environmental and Natural Resources Policy and Training Project/Midwest Universities Consortium for International Activities, Arlington, USA.

Alvarez-Filip, L., Dulvy, N.K., Gill, J.A., Cote, I.M. \& Watkinson, A.R. (2009) Flattening of Caribbean coral reefs: regionwide declines in architectural complexity. Proceedings of the Royal Society B, 276, 3019-3025.

BAKER, R. (1748) A New and Exact Map of the Island of Antigua in America. Museum of Antigua and Barbuda, St. John's, Antigua and Barbuda.

Barbuda Council (2013) The Fisheries Regulations. Antigua and Barbuda. ATG-2013-R-93554.

Barbuda Council (2014) The Barbuda (Fisheries) Regulations. Antigua and Barbuda. ATG-2014-R-99617.

Carpenter, R.C. \& Edmunds, P.J. (2006) Local and regional scale recovery of Diadema promotes recruitment of scleractinian corals. Ecology Letters, 9, 271-280.

Coleridge, H.N. (1826) Six Months in the West Indies. Digitized by the Internet Archive. John Murray, London, UK.

Cramer, K.L., Jackson, J.B.C., Angioletti, C.V., Leonard-Pingel, J. \& Guilderson, T.P. (2012) Anthropogenic mortality on coral reefs in Caribbean Panama predates coral disease and bleaching. Ecology Letters, 15, 561-567. 
Cramer, K.L., Leonard-Pingel, J., Rodriguez, F. \& Jackson, J.B. C. (2015) Molluscan subfossil assemblages reveal the long-term deterioration of coral reef environments in Caribbean Panama. Marine Pollution Bulletin, 96, 176-187.

Cramer, K.L., O’Dea, A., Clark, T.R., Zhao, J. \& Norris, R.D. (2017) Prehistorical and historical declines in Caribbean coral reef accretion rates driven by loss of parrotfish. Nature Communications, 8,14160

De La Rochette, L.S. (1784) A Chart of the Antilles of Charibbee or Caribs Islands with the Virgin Islands. Museum of Antigua and Barbuda, St. John's, Antigua and Barbuda.

Edmunds, P.J. \& Carpenter, R.C. (2001) Recovery of Diadema antillarum reduces macroalgal cover and increases abundance of juvenile corals on a Caribbean reef. Proceedings of the National Academy of Sciences of the United States of America, 98, $5067-5071$.

Ferguson, A. \& Daniel, S. (2015) Montserrat: Coral Cay Conservation Annual Marine Survey Report, Year 2013-2014. Unpublished report. Coral Cay Conservation Expeditions, Farnham, UK.

Fielding, L. (1824) Antigua. Digitized by Caribmap. Altea Gallery, London, UK.

Francis, J.G. (2010) Fourth National Report to the Convention on Biological Diversity: Antigua and Barbuda. Unpublished report. Government of Antigua \& Barbuda, St. Johns, Antigua.

Giglio, V.J., Luiz, O.J. \& Gerhardinger, L.C. (2015) Depletion of marine megafauna and shifting baselines among artisanal fishers in eastern Brazil. Animal Conservation, 18, 348-358.

Godley, B.J., Broderick, A.C., Campbell, L.M., Ranger, S. \& Richardson, P.B. (2004) An assessment of the status and exploitation of marine turtles in Montserrat. In An Assessment of the Status and Exploitation of Marine Turtles in the UK Overseas Territories in the Wider Caribbean, pp. 155-179. Final project report for the Department of Environment, Food and Rural Affairs and the Foreign and Commonwealth Office, Penryn, UK.

Green, S.J., Akins, J.L., Maljković, A. \& Côté, I. (2012) Invasive lionfish drive Atlantic coral reef fish declines. PLoS ONE, 7(3), e32596.

Groombridge, B. \& Luxmoore, R. (1989) The Green Turtle and Hawksbill: World Status Exploitation, and Trade. CITES, Lausanne, Switzerland.

Hays, G.C. (2004) Good news for sea turtles. Trends in Ecology \& Evolution, 19, 349-351.

Hoegh-Guldberg, O., Mumby, P.J., Hooten, A.J., Steneck, R.S., Greenfield, P., Gomez, E. et al. (2007) Coral reefs under rapid climate change and ocean acidification. Science, 318, 1737-1742.

Jackson, J.B.C., Donovan, M., Cramer, K. \& Lam, V. (2014) Status and Trends of Caribbean Coral Reefs: 1970-2012. Global Coral Reef Monitoring Network, IUCN, Gland, Switzerland.

Jackson, J.B.C., Kirby, M.X., Berger, W.H., Bjorndal, K.A., Botsford, L.W., Bourque, B.J. et al. (2001) Historical overfishing and the recent collapse of coastal ecosystems. Science, 293, 629-637.

JefFers, J. (1996) Status of the queen conch, Strombus gigas in Montserrat. In Proceedings of the First International Queen conch conference, San Juan, Puerto Rico, 29-31 July 1996 (eds J. Posada \& G. Garcia-Moliner), pp. 108-109. Caribbean Fisheries Management Council, San Juan, Puerto Rico.

Johnson, A.E. \& JACKson, J.B.C. (2015) Fisher and diver perceptions of coral reef degradation and implications for sustainable management. Global Ecology and Conservation, 3, 890-899.

Luckhurst, B. \& Marshalleck, S. (1995) Current status and assessments of the fisheries for the spiny lobster and conch in the CARICOM region. Proceedings of the 48 th Gulf and Caribbean Fisheries Institute, 48, 73-89.
Luffman, J. (1788) Antigua in the West Indies America. Museum of Antigua and Barbuda, St John's, Antigua and Barbuda.

Maylan, A.B. (1983) Marine turtles of the Leeward Islands, Lesser Antilles. Atoll Research Bulletin, 278, 1-24.

McClenachan, L. \& Cooper, A.B. (2008) Extinction rate, historical population structure and ecological role of the Caribbean monk seal. Proceedings of the Royal Society B Biological Sciences, 275, 1351-1358.

McClenachan, L., Ferretti, F. \& Baum, J.K. (2012) From archives to conservation: why historical data are needed to set baselines for marine animals and ecosystems. Conservation Letters, 5, 349-259.

McClenachan, L., Jackson, J.B.C. \& Newman, M.J.H. (2006) Conservation implications of historic sea turtle nesting beach loss. Frontiers in Ecology and the Environmental, 4, 290-296.

McClenachan, L., Matsuura, R., Shah, P. \& Dissanayake, S.T. M. (2018) Shifted historical baselines reduce willingness to pay for conservation. Frontiers in Marine Science, 5, 1-9.

McClenachan, L., O’Connor, G.E., Neal, B.P., Pandolfi, J.M. \& JACKSON, J.B.C. (2017) Ghost reefs: nautical charts document large spatial scale of coral reef loss over 240 years. Science Advances, 3 , e1603155.

Mumby, P.J. \& Harborne, A.R. (2010) Marine reserves enhance the recovery of corals on Caribbean reefs. PLoS One, 5(1), e8657.

Nicholson, V.E.B. \& Sons (1977) Coco Point and Spanish Point Barbuda. Museum of Antigua and Barbuda, St John's, Antigua and Barbuda.

Nuttting, C.C. (1919) Barbados-Antigua expedition. Narrative and preliminary report of scientific expedition from the University of Iowa to the Lesser Antilles under the auspices of the Graduate College. University of Iowa Studies in Natural History, 8, 82-83.

O’Farrell, S., Luckhurst, B.E., Box, S.J. \& Mumby, P.J. (2016) Parrotfish sex ratios recover rapidly in Bermuda following a fishing ban. Coral Reefs, 35, 421-425.

Paddack, M.J., Reynolds, J.D., Aguilar, C., Appeldoorn, R.S., Beets, J., Burkett, E.W. et al. (2009) Recent region-wide declines in Caribbean reef fish abundance. Current Biology, 19, 590-595.

PAUlY, D. (1995) Anecdotes and the shifting baseline syndrome of fisheries. Trends in Ecology and Evolution, 10, 430.

Peacock, N.A. (1974) A study of the spiny lobster fishery of Antigua and Barbuda. Proceedings of the Gulf and Caribbean Fisheries Institute, 26, 117-130.

Price, D.D., Finniss, D.G. \& Benedetti, F. (2008) A comprehensive review of the placebo effect: recent advances and current thought. Annual Review of Psychology, 59, 1-672.

Randall, C.J. \& van Woesik, R. (2015) Contemporary white-band disease in Caribbean corals driven by climate change. Nature Climate Change, 5, 375-379.

Riddell, M. (1792) Voyages to the Madeira and Leeward Caribbean Isles. P. Hill, Edinburgh, UK.

Ruttenberg, B., Johnson, A.E., Caselle, J., Estep, A., Grenda, D., Marhaver, K. et al. (2013) Ecological Assessment of Barbuda's Marine Ecosystems: Science Supporting the Barbuda Blue Halo Initiative. Waitt Institute, San Diego, USA.

Sáenz-Arroyo, A., Robert, C., Torre, J., Carño-Olvera, M. \& ENRIQUeZ-AndRADE, R. (2005) Rapidly shifting environmental baselines among fisheries of the Gulf of California. Proceedings of the Royal Society B Biological Sciences, 272, 1957-1962.

Troëng, S. \& Rankin, E. (2005) Long-term conservation efforts contribute to positive green turtle Chelonia mydas nesting trend at Tortuguero, Costa Rica. Biological Conservation, 121, 111-116.

Waitt Institute (2016) The Blue Halo Initiative. Http:// waittinstitute.org/bluehaloinitiative/ [accessed 2 January 2016]. 